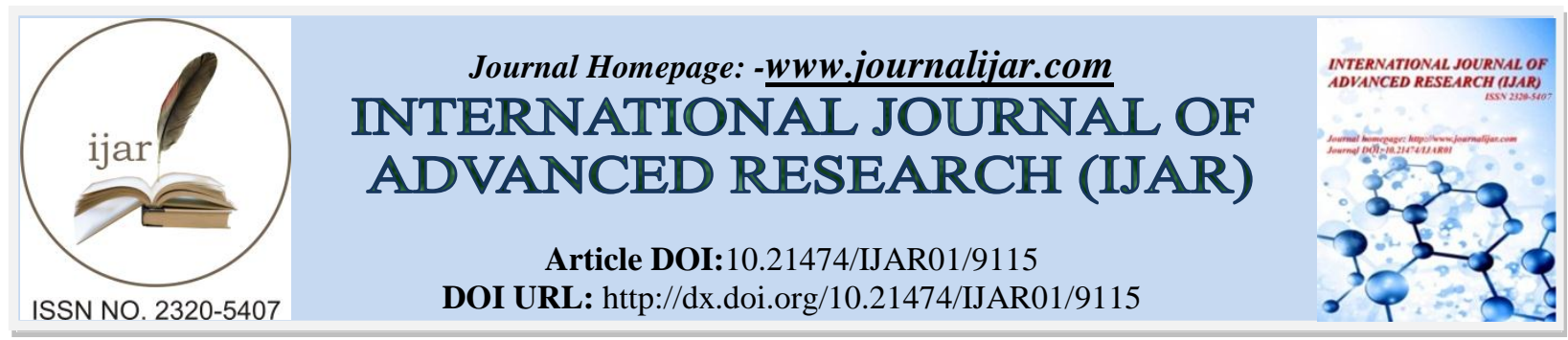

RESEARCH ARTICLE

\title{
WATER POLLUTION AT MIRIK LAKE IN DARJEELING, WEST BENGAL: A LOCAL SOCIO- ECONOMIC IMPACT ANALYSIS.
}

Subhankar Dutta ${ }^{1}$, Sumanta Nayek ${ }^{2}$ and Puja Rai ${ }^{3}$.

1. Ph.D Research Scholar, Maulana Abul Kalam Azad University of Technology, West Bengal 700064, India.

2. Department of Environmental Science, AIES, Amity University Kolkata, West Bengal 700135, India.

3. Department of English, The University of North Bengal, West Bengal 734014, India.

\section{Manuscript Info}

Manuscript History

Received: 22 March 2019

Final Accepted: 24 April 2019

Published: May 2019

Key words:-

Mirik Lake; Water Quality; Tourism;

Socio-Economic Benefit.

\begin{abstract}
Mirik Lake is one of the popular tourist destinations in the Darjeeling mountain area of West Bengal, India. Due to the large number of tourists' inflow in Mirik Lake region, the demand for tourism and hotel industry has surged over the years and substantially contributed to the local economy. However, it has been noted that the water quality of Mirik Lake has been deteriorated over the years due to several reasons. The disposal of waste materials, including garbage, sewage, plastics from the hotels as well as tourists had caused severe pollution to the lake water. In this study, both primary and secondary surveys have been carried out to identify the problem and highlight the possible protectionist measures to combat the crisis. Earlier investigations on Mirik Lake during different time periods clearly established the decline in Mirik Lake's water quality. The results obtained from the primary survey and analysis of data collected implied that tourism growth and hotel industry had played a crucial role in polluting Mirik Lake's water quality. Though majority of the respondents had strongly opined that excessive human influence and hotel industry had resulted in ecological degradation of 'Lake Ecosystem', but they still were in favour of growth of tourism and hotel industry for the socio-economic benefit of the region. The local respondents had suggested some protectionist measures from their perception level, and also wanted Government's as well as local authority's immediate actions to safeguard the Mirik Lake's water quality and subsequently, conserve the 'Lake Ecosystem'.
\end{abstract}

Copy Right, IJAR, 2019,. All rights reserved.

\section{Introduction:-}

Darjeeling, popularly known as the "Jewel in the crown of the East Himalayas", has been recognized as the favourite destination for the nature lovers across the world. Spotted with globally-acclaimed tea gardens, famous mountain peaks of Kanchenjunga range, beautiful mountain lakes, and the presence of diverse types of flora and fauna, it normally attracts a large number of tourists every year. In tune with the fact, earlier investigations have highlighted that lakes in Himalayan regions are one of the most preferred tourist locations for all ages. These lakes are vital water bodies of earth's landscape which are not only source of water, but provide suitable habitats to plants and animals. Also, these lakes enhance aesthetic magnificence of the region and facilitate recreational prospects (Sharma et. al., 2010). The natural conditions of lake ecosystem and its water quality are determined by various 
environmental factors and anthropogenic contributions. In this context, through its research study, (Nayek et. al., 2017) had highlighted that both tourism activities and anthropogenic factors had caused notable deterioration in water quality of 'Aritar Lake' and 'Chaya Taal Lake' in Sikkim Himalaya.

The 'Sumendu Lake', popularly known as the Mirik Lake (ML), is among the most visited tourist destinations of Darjeeling Hill area. The ML of Darjeeling district is considered as one of the beautiful recreational lakes in West Bengal, situated at high altitude approximately 1767 meters. It is shown below, in Figure I. It is located at latitude of $26^{0} 53.163^{\prime}-26^{0} 53.620^{\prime}$ North and longitude of $88^{0} 11.190^{\prime}-88^{0} 10.943$ ' East. The ML stretches over an area of 110 ha. Also, it is approximately $1.25 \mathrm{~km}$ long with depth varying from 3 feet to 26 feet (Roy and Nandi, 2008). The term 'Mirik' emerges from the Lepcha words 'Mir-Yok', which means "place burnt by fire".

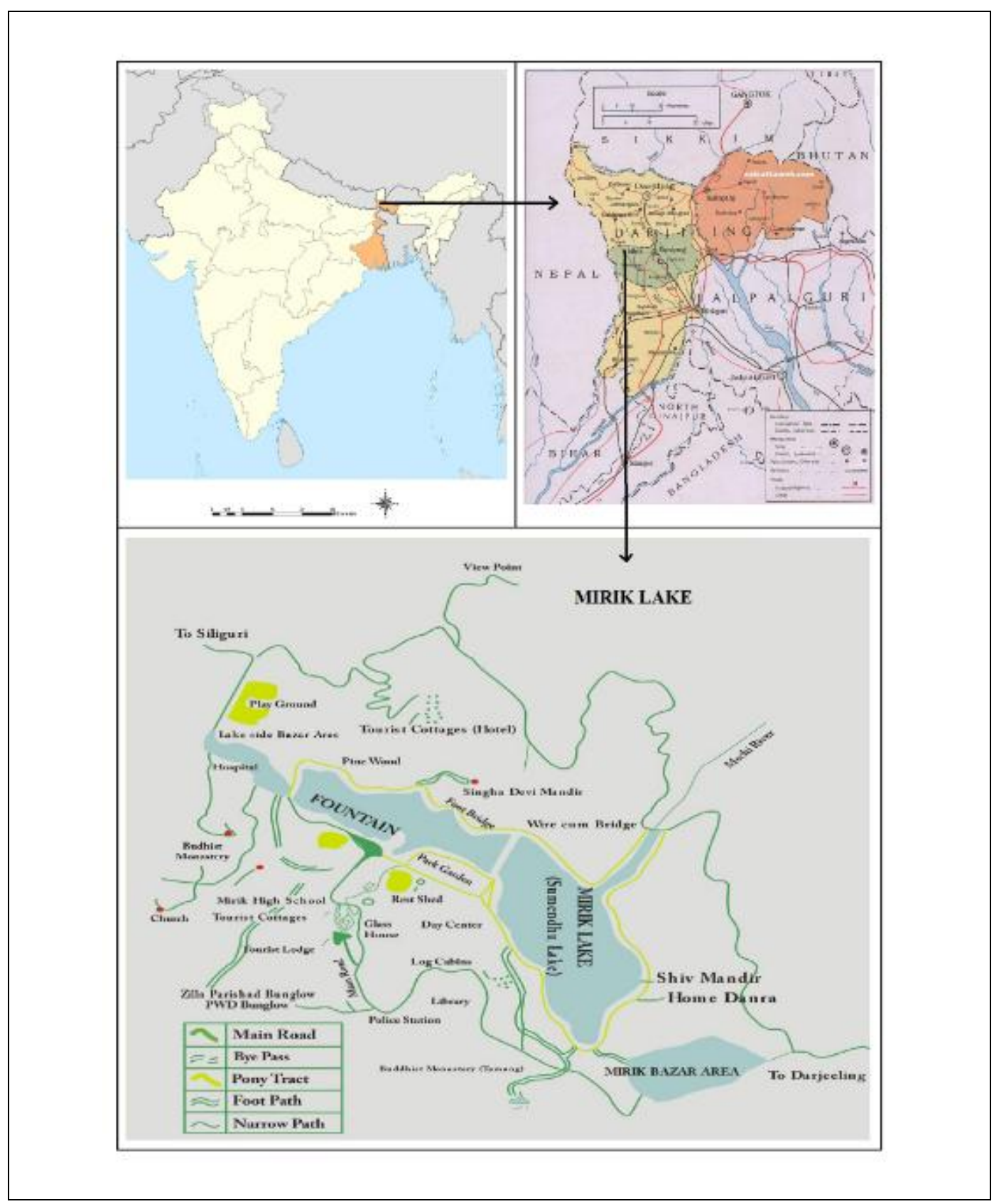

Figure I:- Location Map of the Study Area and Mirik Lake 
The development of tourism activities in Darjeeling hill areas and its impact on socio-economic lives of local people had been discussed and analyzed in various previous research studies. Tourism growth has largely influenced the social texture, ethnic relations in Darjeeling area during the past decades (Subba, 1989). Sherpa (2014) in his research study, highlighted the importance associated to tourism industry for strengthening the human resource development in Darjeeling, West Bengal. Due to the inflow of a large number of domestic as well as foreign tourists to ML during each year, tourism has played a major role in determining the socio-economic status of local residents living adjacent to the lake. Survey conducted on the hotels and resorts of the ML area highlighted that the domestic as well as foreign tourists had usually come in large numbers into various private hotels (Guha, 2016). The growth of transport and tourism sectors has been substantially contributed to the economy of the region. In this regard, Guha (2016) in his study reported that Mirik-Darjiling-Siliguri was considered the main travel route in terms of passenger carried and frequency of flow. Furthermore, the local tourist market along the ML main road, shows the local business pattern and consumer behaviour. Out of authorized 88 shops in the region, $62.54 \%$ are food and beverages shops, 39.44\% of public utility shops and clinic and $9.29 \%$ are medicine shops. There are both leased and personally-owned shops, and daily hawkers which sell the daily necessity products (60\%) (Guha, 2016). However, the growth of tourism industry often directly impacts on the local environment of any particular tourist spot in the Darjeeling Himalaya (Sharma, 2012). The rise in transport facility and construction activities resulted extensive deforestation and destabilization of natural environment in many parts of the Darjeeling mountain areas. Increased number of tourists' inflow has also led to the dumping of solid waste, and consequently pollute the soil and water resources. Several tourism activities like boating and rafting often cause severe water pollution in lakes and rivers of Darjeeling hill areas (Sharma, 2012). Furthermore, the movement of tourists into ecologically sensitive zones has frequently caused destruction and damage to the native plants and animal species mainly through disturbing their natural habitats, trampling and killing (Sharma, 2012). In this connection, environmentalists, scientists and researchers have concerned about the conservation and usability of ML's water from the impact of rising tourism activities in the region over the years. Several research studies were conducted (Roy Biswas, et.al. 2017,Roy Biswas, et.al. 2012, Mondal et.al., 2012, Roy et. al., 2012, Roy and Nandi, 2008) to examine the water quality, biological diversity and environmental degradation of ML, which reveal the evidence of varying degrees of environmental degradation, i.e., water pollution especially occurred due to encroachments, eutrophication (from domestic and commercial effluents), dumping of garbage and outflow of sewages from nearby hotels, siltation, etc. In addition to that, the lack of consciousness among the residents and tourists had aggravated the water pollution level in the ML (Guha 2016).

Earlier studies recognized that the high population density was one of the main reasons for the degradation of water quality of several water bodies including ML in the Himalayan region. In tune with the fact, in this study also, after obtaining the primary data and doing necessary analysis, it has been observed that the polluted water of ML has severely impacted on the socio-economic lives of rural people residing adjacent to the lake during 2017-18.

The current study has been organized in several sections. The section 2 deals with proposed research problems and objectives of the current study. In section 3, the materials and methods of research analyses have been performed and it highlights the data collection and calculation methods of the study. After that, in section 4, results and discussions have been performed. Finally, the section 5 highlights the conclusion related to the study findings and some necessary protectionist steps have been suggested to reduce the water pollution of ML in future.

\section{Research Problem and Objective:-}

The present study is undertaken to explore the following objectives:

1. The importance of tourism industry on the socio-economic growth of people living adjacent to ML;

2. Water quality evaluation of ML (i.e., physico-chemical, biological parameters characteristics of water in relation with various water quality standards);

3. Reasons behind the occurrence of water pollution in ML;

4. Correlation between the water quality of ML and its impact on the socio-economic status of the people living adjacent to the area;

5. Possible counteractive mechanisms and recommendations for controlling the water pollution crisis in the ML.

\section{Materials and Methods:-}

The present study has aimed to analyze the impact of water pollution in ML on the socio-economic status of the people living adjacent to the area. In this context, primary data has been collected from the households and business set-ups like hotels, restaurants, shops, etc. from the adjacent to the ML area mainly during 2018-19. Based on total 
12 questions set in a questionnaire, the responses were collected from 37 local respondents adjacent to the ML region through primary survey. The 12 questions were framed as 1) Gender; 2) Age; 3a) Occupation of the Respondent; 3b) Annual Income (approximately); 4) Source of Drinking Water; 5) Dependence on Mirik Lake's Water for the Daily Usage of Livelihood Work; 6) Whether the growth of tourism industry in Mirik Lake improve socio-economic status; 7) Tourists' Role on Polluting the Water of Mirik Lake; 8) Waste Materials of Hotel Industry Pollute the Water of Mirik Lake; 9) Whether Polluted Water of Mirik Lake Affects the Livelihood and Economic Status Directly/Indirectly; 10) Health Related Problems due to Polluted Water of Mirik Lake; 11) Whether Support to the Inflow of Tourists and Large Number of Hotels besides the Mirik Lake; and 12) Suggestion regarding Improvement of the Water Quality in the Mirik Lake.

After collecting the data from respondents, which includes varied type of responses, corresponding frequencies and relative frequencies have been calculated for all 12 questions separately. Subsequently, frequency distribution pie charts have been developed for all 12 questions. In second part, cross tabulation and Chi-square tests have been performed on several combinations of questions to examine the statistical significant results. The combinations of questions based on conceptual connections are selected as $3 a$ vs $6 ; 3 a$ vs $9 ; 3 a$ vs $10 ; 3 a$ vs $11 ; 3 a$ vs 12 ; 3 b v 6 ; 3 b vs $9 ; 3 \mathrm{~b}$ vs $10 ; 3 \mathrm{~b}$ vs $11 ; 3 \mathrm{~b}$ vs $12 ; 4$ vs $6 ; 4$ vs $9 ; 4$ vs $10 ; 4$ vs $11 ; 4$ vs $12 ; 5$ vs $6 ; 5$ vs $9 ; 5$ vs $10 ; 5$ vs 11 ; and 5 vs 12.

Moreover, Binomial distribution tests have been separately carried out on three questions such as questions 6,10 and 11 in order to check statistical significance of response propensity difference between two types of responses, i.e., 'Yes' and 'No'.

The primary data related statistical calculations have been performed through Microsoft Excel and trial version of SPSS software.In addition to that, the current study has used the secondary data through the references of the past research analyses results conducted by various researchers on ML's water quality during different time periods.

\section{Results and Discussions:-}

Due to the tourism growth, the occurrence of environmental degradation especially to the Himalayan lakes is a matter of concern over the years. In this context, the degeneration of ML in Darjeeling area, because of water pollution, has been analyzed in the literature mostly through descriptive and empirical studies. Several researchers, in their studies have shown that due to the growing tourism activities, the ML is showing evidence of environmental degradation through deterioration of water quality. Different research studies were performed to measure the water quality parameters and ecological status of ML water (Roy Biswas, et.al. 2017,Roy Biswas, et.al. 2012, Mondal et.al., 2012, Roy et. al., 2012, Roy and Nandi, 2008). The results from earlier investigations are summarized in Table I.

The $\mathrm{pH}$ of water is an indicator of acidic or alkaline nature of water. The reported $\mathrm{pH}$ values of ML water ranged from neutral to alkaline condition 6.6 to 8.9, except (Roy and Nandi 2012) who reported minimum pH of lake water as 6.2. The dissolved oxygen (DO) of lake water is very essential for aquatic life, and DO level of $\geq 4$ is an indicator of healthy water body. It is shown in Table I. Based on available reports, the level of DO in examined lake water were reported to vary from 4.3 to $12.6 \mathrm{mg} / \mathrm{L}$, which is considered to be good for aquatic organisms. The biochemical oxygen demand (BOD) $(2.68-5 \mathrm{mg} / \mathrm{L})$ and chemical oxygen demand $(\mathrm{COD})$ levels $(14.88-17.8 \mathrm{mg} / \mathrm{L})$ of lake water were recorded very much within the prescribed standards for surface water and drinking water respectively. The total hardness $(\mathrm{TH})$ and chloride $\left(\mathrm{Cl}^{-}\right)$content of lake water were reported to vary within a range of 13.11 $55.08 \mathrm{mg} / \mathrm{L}$ and $12.4-19.56 \mathrm{mg} / \mathrm{L}$ respectively, which is very much within the prescribed limits for surface water.

Overall observation showed that the values of physic-chemical parameters of lake water were very much within the recommended standards. It is highlighted in Table I. But the values of biological parameters, i.e., total coliform (TC) and faecal coliform (FC) exceeded the prescribed limits for the surface water and human consumption. It is shown in Table I. This could trigger off a matter of concern, and might cause health problem for local inhabitants who were dependent on lake water for daily uses. As per the earlier investigations and available reports, the water pollution in ML was mainly occurred due to siltation, encroachments, eutrophication (from domestic and commercial effluents), dumping of garbage and outflow of sewages from nearby hotels, etc. The obtained results based on previous research studies clearly emphasized the fact that the water quality of ML was degraded due to pollution over the years. In this connection, the present study is an effort to analyze and validate the dominant notion that the water 
pollution has been severely impacted on the socio-economic status of rural people residing adjacent to ML in Darjeeling district of West Bengal.

Table I:- Water Quality of Mirik Lake based on Previous Investigations

\begin{tabular}{|l|l|l|l|l|l|l|l|}
\hline Parameters & $\begin{array}{l}\text { Roy Biswas, Roy Biswas, } \\
\text { et.al. (2017) }\end{array}$ & $\begin{array}{l}\text { Roy and } \\
\text { et.al. (2012) } \\
\text { Nandi } \\
\mathbf{( 2 0 1 2 )}\end{array}$ & $\begin{array}{l}\text { Mondal } \\
\text { et. al. } \\
\mathbf{( 2 0 1 2 )}\end{array}$ & $\begin{array}{l}\text { Roy and } \\
\text { Nandi } \\
\mathbf{2 0 0 8})\end{array}$ & $\begin{array}{l}\text { IS } \\
\text { Standards } \\
\text { for Inland } \\
\text { Surface } \\
\text { Water }^{\mathbf{a}}\end{array}$ & $\begin{array}{l}\text { BIS } \\
\text { Standards } \\
\text { for } \\
\text { Drinking } \\
\text { Water }^{\mathbf{b}}\end{array}$ \\
\hline pH & 6.8 & 6.91 & $6.2-8.9$ & $6.61-7.36$ & 8.47 & $6.5-8.5$ & $6.5-8.5$ \\
\hline DO (mg/L) & 8 & 8.01 & $4.3-12.6$ & $5.26-9.09$ & 5.76 & 4 & $\geq 5$ \\
\hline $\begin{array}{l}\text { BOD } \\
(\mathbf{m g} / \mathbf{L})\end{array}$ & 5 & 4.62 & -- & $2.68-4.8$ & -- & 30 & $<5$ \\
\hline $\begin{array}{l}\text { COD } \\
(\mathbf{m g} / \mathbf{L})\end{array}$ & 17.8 & 14.88 & -- & -- & -- & 250 & $<10$ \\
\hline TH (mg/L) & -- & -- & $13.11-$ & $\begin{array}{l}13.25- \\
26.88\end{array}$ & 55.08 & $200-600$ & $200-600$ \\
\hline Cl (mg/L) & 12.4 & 13.14 & $13.7-22$ & $\begin{array}{l}15.65- \\
19.56\end{array}$ & 14.67 & $250-1000$ & -- \\
\hline $\begin{array}{l}\text { TC (MPN } \\
\text { per 100 ml) }\end{array}$ & 102 & 44.86 & -- & -- & -- & 0 & 0 \\
\hline $\begin{array}{l}\text { FC (MPN } \\
\text { per 100 ml) }\end{array}$ & 30 & 23.28 & -- & -- & -- & 0 & 0 \\
\hline
\end{tabular}

${ }^{\mathrm{a}}$ IS 2296:1982.Tolerance limits for inland surface water subject to pollution. Bureau of Indian Standard, New Delhi. ${ }^{\mathrm{b}}$ Indian standard drinking water specification (second revision) BIS 10500:2012, New Delhi.

For the first set of statistical interpretation, frequency distribution and relative frequency distribution results have been studied for different combinations of questions respectively. In this context, firstly, two questions such as (question no. 4) 'Source of Drinking Water' and (question no. 5) 'Dependence on Mirik Lake's Water for the Daily Usage of Livelihood Work' have been selected for interpretation.

'Source of Drinking Water' and 'Dependence on Mirik Lake's Water for the Daily Usage of Livelihood Work':

After studying the frequency distribution and relative frequency distribution results of questions 4 (which is shown in Figure IIa) and 5 (which is shown in Figure IIb), it has been noted that the local people do not depend on ML's water for drinking purpose (which is highlighted in Figure IIa). However, 19\% of people have responded that they rely on ML's water only for household works. In contrast, $81 \%$ of people respond that they do not depend on ML's water for household purposes as well. (shown in Figure IIb). 


\section{Frequency Distribution Pie Chart - Source of Drinking Water}

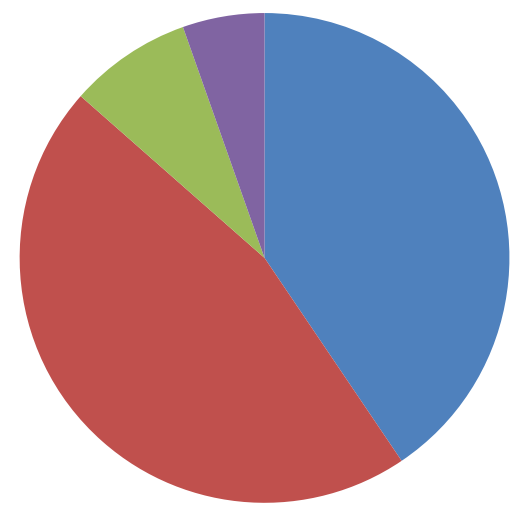

In House

- Locality

Municipality

- Others

Figure IIa:- Frequency Distribution Pie Chart - Source of Drinking Water.

\section{Frequency Distribution Pie Chart - Dependence on Mirik Lake's Water for the Daily Usage of Livelihood Work}

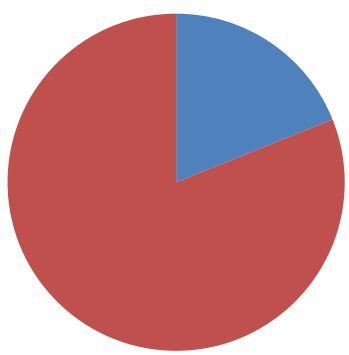

Yes

No

Figure IIb:- Frequency Distribution Pie Chart - Dependence on Mirik Lake's Water for the Daily Usage of Livelihood Work

Secondly, two questions such as (question no. 7) 'Tourists' Role on Polluting the Water of Mirik Lake' and (question no. 8) 'Waste Materials of Hotel Industry Pollute the Water of Mirik Lake' have been selected for interpretation.

'Tourists' Role on Polluting the Water of Mirik Lake' and 'Waste Materials of Hotel Industry Pollute the Water of Mirik Lake':

Results obtained from frequency distribution and relative frequency distribution of questions 7 (which is shown in Figure IIIa) and 8 (which is highlighted in Figure IIIb), it has been noticed that the tourists' have played a major role of polluting the water of ML. In addition to that, the hotel industry has also played a crucial part of polluting the water of ML through disposal of waste materials. In this connection, it has been observed that $38 \%$ of tourists' pollute the ML water through simultaneous disposal of both garbage and plastics. Followed by 19\%, 16\% and 13\% tourists' pollute the ML water through disposal of plastics, garbage and combination of garbage, sewage and plastics respectively (which is shown in Figure IIIa). On the other hand, it has been observed that $38 \%$ of waste materials 
including both garbage and sewage disposal from hotel industry have polluted the ML water. Moreover, 32\% and $30 \%$ of waste materials such as garbage and sewage disposal from hotel industry have polluted the ML water respectively (which is highlighted in Figure IIIb).

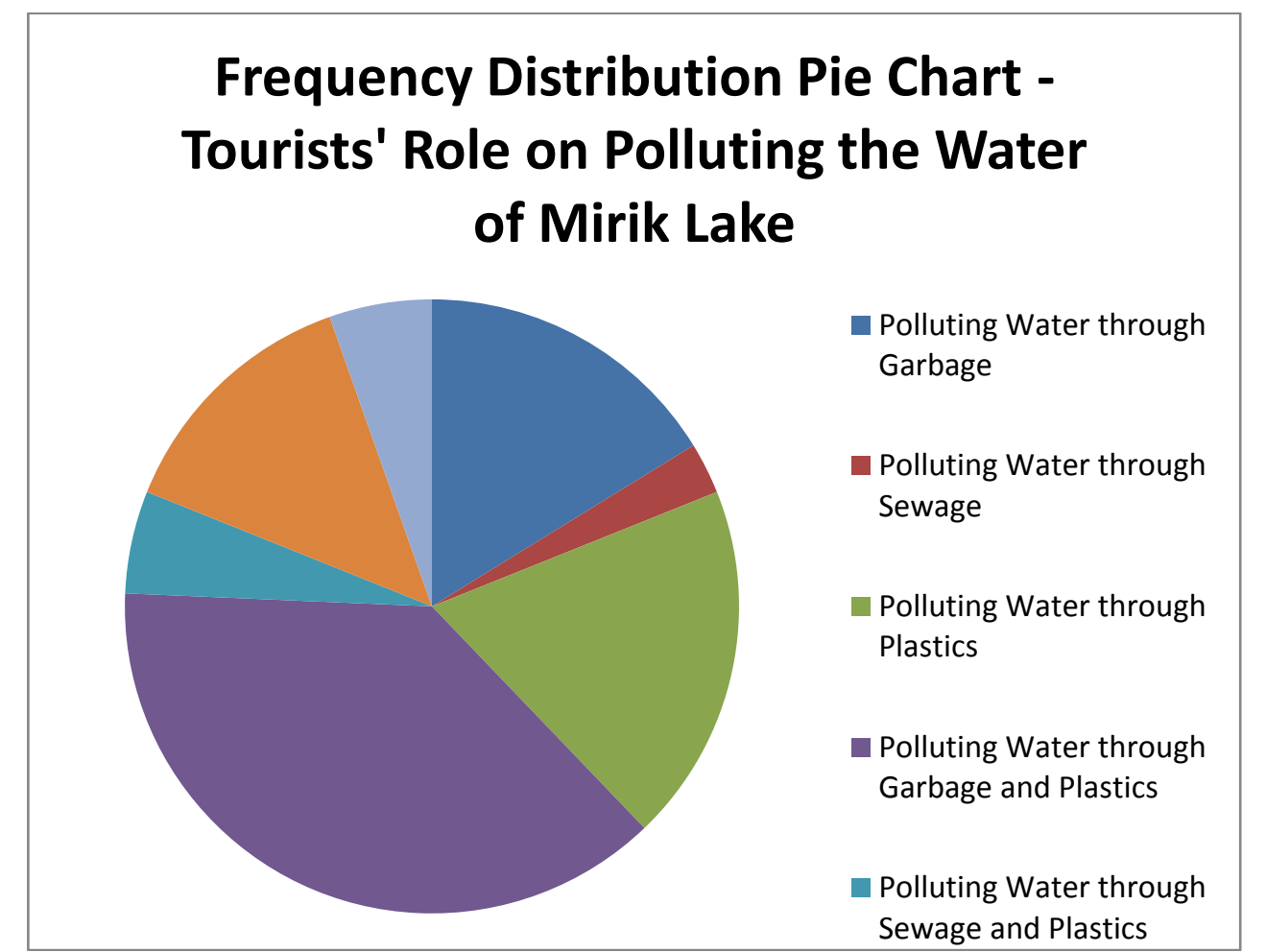

Figure IIIa:- Frequency Distribution Pie Chart - Tourists' Role on Polluting the Water of Mirik Lake

\section{Frequency Distribution Pie Chart - Waste Materials of Hotel Industry Pollute the Water of Mirik Lake}

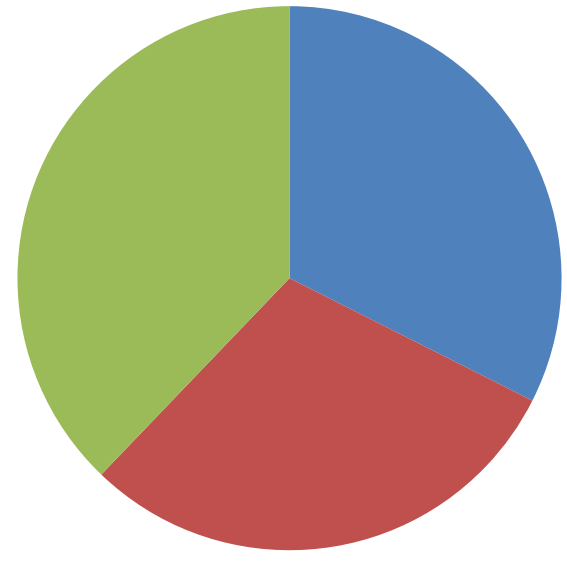

- Polluting Water through Garbage

- Polluting Water through Sewages from Hotel

Polluting Water through Garbage and Sewages from Hotel

Figure IIIb:- Frequency Distribution Pie Chart - Waste Materials of Hotel Industry Pollute the Water of Mirik Lake 
Thirdly, two questions such as (question no. 9) 'Whether Polluted Water of Mirik Lake Affects the Livelihood and Economic Status Directly/Indirectly' and (question no. 11) 'Whether Support to the Inflow of Tourists and Large Number of Hotels besides the Mirik Lake' have been selected for interpretation.

'Whether Polluted Water of Mirik Lake Affects the Livelihood and Economic Status Directly/Indirectly' and 'Whether Support to the Inflow of Tourists and Large Number of Hotels besides the Mirik Lake':

After analyzing the frequency distribution and relative frequency distribution results of questions 9 (which is shown in Figure IVa) and 11 (which is highlighted in Figure IVb), it has been noted that there exists a paradoxical opinion among the common people of ML region regarding the water pollution effects on ecology and support of tourism and hotel industry growth in the area. About $70 \%$ of people have acknowledged the fact that the polluted water of ML has caused the ecological degradation in the region. Moreover, $10 \%$ of people have stated that the polluted water of ML has caused the loss of income (which is shown in Figure IVa). On the other hand, 68\% of people have responded in favour of tourism and hotel industry growth in the region. In contrast, $32 \%$ of people have not supported the tourism and hotel industry growth in the ML area (which is highlighted in Figure IVb).

\section{Frequency Distribution Pie Chart - Whether Polluted Water of Mirik Lake Affects the Livelihood and Economic Status}

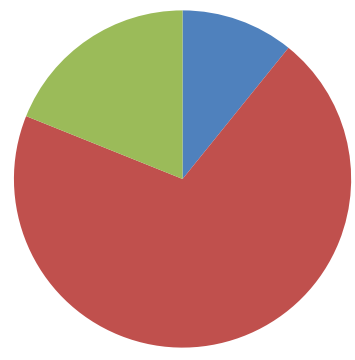

- Loss of Income

Ecology Degradation

No

Figure IVa:- Frequency Distribution Pie Chart - Whether Polluted Water of Mirik Lake Affects the Livelihood and Economic Status

\section{Frequency Distribution Pie Chart - Whether Support to the Inflow of Tourists and Large Number of Hotels besides the Mirik Lake}

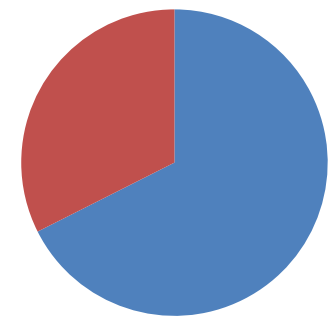

Yes

No

Figure IVb:- Frequency Distribution Pie Chart - Whether Support to the Inflow of Tourists and Large Number of Hotels besides the Mirik Lake 
Furthermore, it is observed from the frequency distribution and relative frequency distribution analyses that the local people have strongly recommended the pollution control mechanism (about 60\%) in the ML area. In addition to that, approximately $29 \%$ of responses have opined in favour of restrictions of tourism activities for the sake of protecting the ML's water from pollution. Besides, around $11 \%$ of responses have stated the importance of creating awareness among local people as well as tourists about keeping the ML's water pollution-free.

For better understanding of statistical interpretation, cross tabulation and Chi-square tests for the following combinations of questions are executed, such as $3 \mathrm{a}$ vs $6 ; 3 \mathrm{a}$ vs $9 ; 3 \mathrm{a}$ vs $10 ; 3 \mathrm{a}$ vs $11 ; 3 \mathrm{a}$ vs $12 ; 3 \mathrm{~b}$ vs 6 ; $3 \mathrm{~b}$ vs 9 ; $3 \mathrm{~b}$ vs $10 ; 3 \mathrm{~b}$ vs $11 ; 3 \mathrm{~b}$ vs $12 ; 4$ vs $6 ; 4$ vs $9 ; 4$ vs $10 ; 4$ vs $11 ; 4$ vs $12 ; 5$ vs $6 ; 5$ vs $9 ; 5$ vs $10 ; 5$ vs 11 ; and 5 vs 12 . Subsequently, for each combination of questions, the cross tabulation and Chi-square tests have shown statistically insignificant results (level of significance was taken as 0.05). As the results obtained from the Chi-square tests are not significant, so, the opinion about occupation; annual income of local inhabitants; source of drinking water; and dependence on ML's water for the daily work; are independent of characteristics on issues such as growth of tourism; impact of water pollution on local livelihoods and economic status; health related problems due to water pollution; tourists inflow and hotel industry besides ML; and suggestion about improvement of the water quality.

Apart from frequency distribution and cross tabulation methods, Binomial tests have been carried out to examine the significance of the respondents' responses. For this purpose, three questions have been selected, i.e., i) whether the growth of tourism industry in ML improve the socio-economic status of local livelihoods, ii) whether health related problems occur due to polluted water of ML and iii) whether local people support to the inflow of tourists and large number of hotels besides ML. After computing Binomial distribution tests separately, it is observed that all three outcomes are statistically significant. It is shown below, in Table II.

Table II:- Significance Test Results (Binomial Distribution)

Binomial Test on Whether the Growth of Tourism Industry in Mirik Lake Improve Socio-Economic Status

\begin{tabular}{|l|l|l|l|l|l|l|}
\hline & & Category & N & $\begin{array}{l}\text { Observed } \\
\text { Prop. }\end{array}$ & $\begin{array}{l}\text { Test Prop. } \\
\text { Exact Sig. (2- } \\
\text { tailed) }\end{array}$ \\
\hline WhetherTourismImprovesSocio-EconomicStatus & Yes & 1.0 & 25 & .68 & .50 \\
& No & .0 & 12 & .32 & .047 \\
& & 37 & & \\
\hline
\end{tabular}

Binomial Test on Health Related Problems due to Polluted Water of Mirik Lake

\begin{tabular}{|c|c|c|c|c|c|c|}
\hline & & Category & $\mathrm{N}$ & $\begin{array}{l}\text { Observed } \\
\text { Prop. }\end{array}$ & Test Prop. & $\begin{array}{l}\text { Exact Sig.* (2- } \\
\text { tailed) }\end{array}$ \\
\hline $\begin{array}{l}\text { HealthRelatedProblemsduetoPollutedWaterof } \\
\text { MirikLake }\end{array}$ & $\begin{array}{l}\text { Yes } \\
\text { No } \\
\text { Total }\end{array}$ & $\begin{array}{l}1.0 \\
.0\end{array}$ & $\begin{array}{l}8 \\
29 \\
37\end{array}$ & $\begin{array}{l}.22 \\
.78 \\
1.00\end{array}$ & .50 & .001 \\
\hline
\end{tabular}

Binomial Test on Whether Support to the Inflow of Tourists and Large Number of Hotels besides Mirik Lake

\begin{tabular}{|c|c|c|c|c|c|c|}
\hline & & Category & $\mathrm{N}$ & $\begin{array}{l}\text { Observed } \\
\text { Prop. }\end{array}$ & Test Prop. & $\begin{array}{l}\text { Exact Sig. }{ }^{*}(2- \\
\text { tailed })\end{array}$ \\
\hline $\begin{array}{l}\text { WhetherSupporttotheInflowofTouristsandLarge } \\
\text { NumberofHotels besides Mirik Lake }\end{array}$ & $\begin{array}{l}\text { Yes } \\
\text { No } \\
\text { Total }\end{array}$ & $\begin{array}{l}1.0 \\
.0\end{array}$ & $\begin{array}{l}25 \\
12 \\
37\end{array}$ & $\begin{array}{l}.68 \\
.32 \\
1.00\end{array}$ & .50 & .047 \\
\hline
\end{tabular}

*Level of Significance 0.05

The outcomes of binomial distribution tests imply the following - First of all, the growth of tourism industry improves the socio-economic lives of the local natives in the ML region, i.e., approximately, 68\% of people's responses are in favour of this notion. In contrast, around $32 \%$ of the responses highlight that the tourism growth will not improve their socio-economic status. Secondly, the opinion regarding the health related problems occurred 
due to the polluted water of ML is not true in reality. The findings show that about $78 \%$ of the opinion suggests that the health related problems among the local residents have not occurred because of the polluted water of ML. Only $22 \%$ responses highlight that health related pollution occurs due to polluted water of ML. Thirdly, around $68 \%$ of opinion states that the local people support the tourism and hotel industry growth adjacent to the ML. Contrastingly, approximately $32 \%$ of responses do not support the inflow of tourists and existence of large number of hotels besides the ML region.

\section{Conclusion:-}

From commercial point of view, tourism growth had strengthened the local economy of the lake area. But despite the growth of tourism industry in Darjeeling area, the severity of pollution has become a major environmental concern. The increased in tourists' inflow has often caused the rise in solid wastes, plastics dumping in and around the surrounding lake areas, thereby creating severe water pollution to the lakes and rivers in the Darjeeling region. From the survey results, it is found that the local people of ML area are in favour of tourism and hotel industry growth for socio-economic development, and they are also aware of the prevailing water pollution of the ML. In order to combat the water pollution crisis, some conservationist steps need to be implemented, such as execution of proper drainage system, solid waste disposal methods in ML's surrounding areas, banning of using plastics, imposing spot fine for causing pollution, creating general awareness among tourists' and more government initiatives to ensure pollution-free ecosystem in and around the ML area. In addition to that, strict implementations of preventive measures as per the guidelines of Bureau of Indian Standards (BIS), Water Supply \& Sanitation Collaborative Council and World Health Organization (WHO) should be taken into consideration for reducing the water pollution crisis in ML. Besides that, the balanced economic and regulatory instruments approach such as 'Polluter-pays-principle' can be applied on the polluters like tourists, hotel owners of the ML area to reduce the pollution level. Furthermore, sustainable water pollution control techniques such as wastewater and sewage treatment, in situ bioremediation methods can be executed in the study area to ensure the lessening of ML's water pollution level.

\section{Acknowledgements:-}

The authors are thankful to Dr. Diganta Mukherjee, Associate Professor, Sampling and Official Statistics Unit, Indian Statistical Institute, Kolkata, for his invaluable suggestions, which improved the research work substantially.

\section{References:-}

1. Bhutia, S. (2014). The Role of Tourism for Human Resource Development in Darjeeling District of West Bengal, India. Journal of Tourism and Hospitality Management, Vol. 2, No. 1, pp. 113-128.

2. Guha, P. (2016). An Assessment of the Mirik Lake and the local neighborhood - A dynamic perception. Knowledge, 1(1): 62-71.

3. Indian standard drinking water specification (second revision) BIS 10500:2012, New Delhi.

4. IS 2296:1982.Tolerance limits for inland surface water subject to pollution. Bureau of Indian Standard, New Delhi.

5. Mondal, D., Pal, J., Ghosh, T.K., and Biswas, A.K., (2012). Abiotic characteristics of Mirik Lake water in the hills of Darjeeling, West Bengal, India. Adv. Appl. Sci. Res., 3(3):1335-1345.

6. Nayek, S., Choudhury, I.H., and Roy, S. (2017). Water quality assessment of two constructed lakes (Aritar Lake \& Chaya Taal Lake) in Sikkim during winter \& summer season. Int. J. Adv. Res., 5(7): 1411-1417.

7. Roy, M. and Nandi, N.C., (2012). Limnology, biodiversity and management issues of Mirik Lake, West Bengal. J. Environ. \& Sociobiol., 9(1): 73-77.

8. Roy, M. and Nandi, N.C., (2008). Macrozoobenthos of some Lacustrine wetlands of West Bengal, India. In: Sengupta, M. and Dalwani, R. (Eds). Proceedings of Taal 2007, The 12th World Lake Conference: 506-513.

9. Roy M.B., Roy P.K., Majumder M., Biswas A. (2017). Sustainable City around Indian Alpine Wetland: A Case of Mirik Lake, West Bengal. In: Sharma P., Rajput S. (eds) Sustainable Smart Cities in India. The Urban Book Series. Springer, Cham.

10. Roy, M.B., Roy, P.K., Mazumdar, A., and Samal, N.R., (2012). Water quality monitoring by multivariate statistical methods in the Alpine Lake of Darjeeling Himalaya, India. Int. J. Adv. Sci. Tech. Res., 6(2): 115-131.

11. Sharma, M.P., Kumar, A., Rajvanshi, S. (2010). Assessment of Trophic State of Lakes: A case study of Mansi Ganga lake in India. Hydro Nepal., 6: 65-72. 
12. Sharma, R.P., (2012). "Chapter 6 - Development of Tourism in Darjeeling Hills and its Impact" of the thesis "A Study in environmental degradation in the Darjeeling hill areas". Department of Geography and Applied Geography, University of North Bengal.

13. Subba, T.B. (1989). Sociological consequences of tourism in Darjeeling." In: Singh, S.C (Ed). Impact of tourism on Mountain environment. Research India Publications, pp 305-314. 